\title{
Index of the cycle of money - The case of Greece
}

Constantinos Challoumis $\uparrow$

N.K.U.A. (National Kapodistrian University of Athens), Greece

\begin{tabular}{l}
\hline ARTICLE INFO \\
\hline Article History \\
Received 16 July 2021 \\
Accepted 31 August 2021 \\
\hline JEL Classifications
\end{tabular}

F6, F40, F43, F62, F63

Keywords:

Index of the cycle of money, Greece, the cycle of money

\section{ABSTRACT}

\section{Purpose:}

The purpose of this paper is to apply the theory of cycle of money in the case of Greece. Prior works have determined the economic characteristics of the case of Latvia, Serbia, and Bulgaria, according to the concept of the theory of cycle of money. The index of the cycle of money suggests how an economic system should counteract a monetary and fiscal crisis and studies how well-structured is Greece's economy. The estimations of the index of the cycle of money of Greece are compared with the global average index of the cycle of money. The results reveal that Greece is above the average global value. Then, Greece's results reveal that it is a well-structured economy and can face an economic crisis. The current work is important as represents the strength of Greece's economy with emphasis to the period of $2012-2017$, of financial and economic crisis. The theory of the cycle of money covers the gap that exists for the structure and functionality of the economy, which formed on the derivative of GDP, giving the cycle of money. Moreover, it is the only theory that enhances the economy, without any negative effect of the fiscal or the monetary policy, as uses the same amount of money of an economy appropriately.

Design/methodology/approach:

The applied methodology stands on the analysis of the theory, mathematical, statistical, and econometrical results.

Findings:

The study found that the general index of the cycle of money for the case of Greece is 0.72 , showing that the distribution of money is at the upper level, revealing the very good strength of the Greek economy, with a very well-based economic structure and high economic functionality, meaning high distribution and reuse of money.

Research limitations/implications:

This work is from a project for multiple countries. Concluding, the recent decision of $15 \%$ minimum tax to the international companies complies with the Fixed Length Principle of the theory of cycle of money that developed the last years.

Originality/value:

This study contributes to the theory of the cycle of money and shows that Greece belongs to the countries which have top rates to the distribution of money, explaining why Greece against to huge financial crisis of the prior decade, achieved to recovered.

\footnotetext{
1. Introduction

The paper's argument and novelty are that Greece belongs to the countries with a very good index of the cycle of money, meaning high economic functionality, interpreting appropriate performance to the distribution and the reuse of money. This high economic functionality according to these terms, shows that the structure of the economy is appropriately formed. The highest index of the cycle of money is that of Luxemburg; as has a value of 0.98 for the general index of the cycle of money. Then, Luxemburg's economy would not be affected by any type of economic crisis or depression.

The theory of the cycle of money doesn't have negative effects that monetary and fiscal policy occur, as it is no external influence on the magnitudes of economies happen, but by an appropriate tax policy the same amount of money an economy is used more effectively, reflecting and the structure of the economy. This doesn't mean that a fiscal or monetary policy should not be applied pending the case. The theory of the cycle of money studies the economic
} 
functionality of an economy, through the distribution and reuse of money, permitting to conclude the appropriate structure of the economy.

This work studies the dynamic of the economy, of Greece, using the concept of the cycle of money. The prior results of Latvia's, Serbia's, and Bulgaria's conclusions revealed the behavior of these countries to a potential crisis. Following a similar concept, it is examined the case of Greece. The theoretical background of the cycle of money supports that the dynamic of an economy is formed on the idea of the number of times that money is used in an economy. An economy should be considered not as a closed system, but as a system with fragments. An economy with fragments means that the economy interacts with other economies but simultaneously protects its money (Constantinos Challoumis, $2021 \mathrm{a}, 2021 \mathrm{c}$, $2021 b)$. An amount of money in many cases is getting out from an economy to external banks, or other economies. The main idea is that the bigger companies and the international companies in most cases are saving their money to external banks and economic heavens. Then, using this theory, the tax authorities should put an additional tax on these kinds of companies to decline the losses to the economy. Additionally, the smaller companies and the freelancers should be taxed with lower tax rates. Then, it would be plausible to increase the dynamic of the economy. Moreover, the factories, the know-how services of big companies, the health care system, and the educational system comprise a special case for the economy, as belong to those cases where the taxes improve the quality of the economy (Stern, 2015; Ud Din, Mangla and Jamil, 2016; Castaño, Méndez and Galindo, 2016; Miailhe, 2017; Challoumis, 2018; Tvaronavičienè, Tarkhanova and Durglishvili, 2018; Campos, Braga and Correia, 2019; Lajas and Macário, 2020; Forson, 2020; Jia et al., 2020; Constantinos Challoumis, 2020). The factories and the big know-how companies increase the cycle of money, as they do not substitute the activities of the small-medium companies and the freelancers. The educational and health care systems improve the quality of the economy, making the whole economy better.

Thus, the applied methodology is hinged on the concept of the index of the cycle of money. The cause to define the general index of the cycle of Greece permits to conclude country's strength to a crisis. The results comply with the economic condition of Greece, as its high distribution and reuse of money, allowed to counteract the economic crisis.

Therefore, this paper sought to make clear how the concept of the cycle of money, works in an actual case scenario like this of the economic system of Greece. The index of the cycle of money suggests how an economic system ought to counteract a monetary crisis and examines how well-structured is a country's economy. The estimations of the index of the cycle of money of Greece are used for a comparison with the global average index of the cycle of money (Erickson, 2016; Arai, Naito and Ono, 2018; Bakaki and Bernauer, 2018; Korenik and Wegrzyn, 2020; Montmarquette, 2020; Pircher, 2020; Rumayya et al., 2020; Haskel and Westlake, 2021). The results reveal that Greece is above the average global value and therefore could face an economic crisis, as it is a well-structured economy. The concept of the cycle of money reveals that the taxes return to the economy, in the case of the education and the health care system (these are exclusions from the mainstream where taxes support the economy). But, the mainstream is that the tax authorities should maintain the taxes to the lowest level. For small and medium companies, the government should protect them with very low taxes and contemporaneously should put greater taxes on the larger companies. But, there is a type of big and international companies that should have low tax rates, as these types of companies are not substituting the activities of smaller companies ('The East Asian miracle: economic growth and public policy', 1994; 'Income taxes, public fiscal policy and economic growth', 2014; Acs and Szerb, 2007; Oueslati, 2015; Acs et al., 2016; Arabyan, 2016; GVELESIANI, 2019; Ladvocat and Lucas, 2019; Wu et al., 2019; Rashid, Warsame and Khan, 2020).

The cases of Latvia, Serbia, and Bulgaria revealed that are above the limit of 0.2 (this is the minimum allowed limit to be able an economy to face a crisis) and in general above the average rate of 0.5 , concluding that these countries can counteract a potential crisis. The fixed-length principle can enforce the cycle of money (Challoumis, 2019a). The case of Latvia presented the condition of the country's economy and how to react to an economic crisis, according to the index of the cycle of money. These results are formed on the theoretical approach of the theory of the cycle of money, where this theory presents that to an economy the taxes return to the society, basically to the case of the education and the health system. But, the main rule is that the authorities should keep the taxes as low as is plausible, for the medium or small economic units (meaning any kind of economic unit e.g. freelancers), and companies. The arm's length principle is the principle where the authorities use to apply the taxes to international and to groups of companies.

The arm's length principle is the method that the tax authorities estimate the tax obligations of the companies, which participate in international transactions. The authorities using the arm's length principle are tough to obtain the controlled transactions, as the international companies offer similar data with that of the uncontrolled transactions and they are hiding with a purpose to avoid paying taxes. Therefore, the government needs to apply the fixed-length principle. The fixed-length principle indicates that the companies of controlled transactions manage transactions and achieve to avoid tax-paying (Cai, 2017; Abdelkafi, 2018; Challoumis, 2019a; Constantinos Challoumis, 2019; Bernasconi and Espinosa-Cristia, 2020; C. Challoumis, 2020; Jeon, Kim and Kwon, 2020). Then, according to the fixed-length principle, international companies should pay plus a fixed amount of tax or at least a minimum fixed tax. In that way, the cycle of money is enhanced, because the larger companies generally receive the money out the society and the economy and save them to international banks. Therefore, that money is lost from society, diminishing consumption. According to the fixed-length principle, the local companies which save their money to local banks should have lower tax rates.

The fixed-length principle serves the theory of the cycle of money, where the small and medium companies are paying lower taxes than the larger companies, which substitute their commercial activities. On the contrary, the arm's length principle estimates the taxes standing on methodologies provided by the companies that make international transactions (Porter, 2007; Kalambokidis, 2014; Bowling, Boyland and Kirkeby, 2019; Lajas and Macário, 2020; Mueller, 2020). In that way, the large companies cover the activities of the smaller companies. Finally, the mainstream is that small and medium companies robust the distribution of money to a country's economy as usually they don't save their 
money out of the country's economic system, and reuse the money inside the economy (Stern, 2015; AICPA, 2017; Cascajo et al., 2018; Le Bodo et al., 2019). Therefore, the money distributed inside the economy many times increases the cycle of money. The reason why money increases the cycle of money is obvious according to eq. (4) of the general index of the cycle of money. The last decision of $\mathrm{G} 7$ for $15 \%$ minimum tax for the international companies complies with the Fixed Length Principle of the cycle of money; where last years suggested an additional standard tax to these companies as they don't reuse the money to country's economy, but they save them to tax heaves and to international banks (Challoumis, 2019b).

\section{Review of Literature}

The facets of Latvia, Serbia, and Bulgaria revealed that are above the limit of 0.2 and in general above the average rate of o.5, concluding that these countries can counteract a potential crisis. The fix length principle can enforce the cycle of money. The case of Latvia presented the condition of the country's economy and how to react to an economic crisis, according to the index of the cycle of money. These results are formed on the theoretical approach of the theory of the cycle of money, where this theory presents that to an economy the taxes return to the society, basically to the case of the education and the health system. But, the main rule is that the authorities should keep the taxes as low as is plausible, for the medium or small economic units (meaning any kind of economic unit e.g. freelancers), and companies. The arm's length principle is the principle where the authorities use to apply the taxes to international and to groups of companies. The arm's length principle is the method that the tax authorities calculate the tax obligations of the companies, which participate in international transactions. The authorities using the arm's length principle are tough to obtain the controlled transactions, as the international companies offer similar data with that of the uncontrolled transactions and they are hiding with a purpose to avoid paying taxes (Feinschreiber, 2004). Therefore, the government needs to apply the fixed-length principle. The fixed-length principle indicates that the companies of controlled transactions manage transactions and achieve to avoid tax paying. Then, according to the fixed-length principle, international companies should pay plus a fixed amount of tax. The cycle of money is enhanced because the larger companies generally receive the money out of the society and the economy and save them to international banks. Thus, that money is lost from society, diminishing consumption. Then, according to the fixed-length principle, the local companies which save their money to local banks should have lower tax rates (Jomo and Wee, 2003; Bakaki and Bernauer, 2018; Cornelsen and Smith, 2018; Bhuiyan and Farazmand, 2020; Kroth, Geremia and Mussio, 2020; Rumayya et al., 2020).

Concluding, the fixed-length principle serves the theory of the cycle of money, where the small and medium companies are paying lower taxes than the larger companies, which substitute their commercial activities. On the other hand, the arm's length principle estimates the taxes standing on methodologies provided by the companies that make international transactions (Marume, 2016; Constantinos Challoumis, 2020; Maxwell, 2020). In that way, the large companies cover the activities of the smaller companies. The mainstream is that small and medium companies robust the distribution of money to a country's economy as usually they don't save their money out of the country's economic system, and reuse the money inside the economy. The money distributed inside the economy many times increases the cycle of money. The reason where the money increases the cycle of money is obvious according to eq. (4) of the general index of the cycle of money.

The last decision of $15 \%$ minimum tax for the international companies complies with the Fixed Length Principle of the cycle of money; where last years suggested an additional standard tax to these companies as they don't reuse the money to country's economy, but they save them to tax heaves and to international banks.

\section{Methodology}

The methodology applied for the current study is presented below, being in the same line with the presented theory. The calculations of the cycle of money are clarified by the following mathematical types of the work "Mathematical background of the theory of cycle of money":

$$
\begin{aligned}
& c_{y}=c_{m}-c_{\alpha} \\
& c_{y}=\frac{d x_{m}}{d m}-\frac{d x_{m}}{d a} \\
& i_{c y}=Y * b_{d} \\
& g_{\text {cyCountry }}=\frac{c_{y c o y n t r y ' s}}{c_{y \text { Average }}+c_{y c o y n t r y ' s}} \text { or } \frac{i_{\text {cycoyntry's }}}{i_{\text {cyAverage }+i_{\text {cycoyntry's }}}} \\
& g_{\text {cyAverage }}=\frac{c_{y \text { Average }}}{c_{y \text { Average }}+c_{y \text { Average }}} \mathrm{V} \frac{i_{\text {cyAverage }}}{i_{\text {cyAverage }}+i_{\text {cyAverage }}}=0.5
\end{aligned}
$$

The $c_{m}$ is the velocity of financial liquidity, $c_{\alpha}$ is the velocity of escaped savings and $c_{y}$ is the cycle of money. The $i_{c y}$ is the index of the cycle of money, $Y$ is the national income or GDP, and $b_{d}$ is the bank deposits of the country. In addition, $g_{\text {cycountry }}$ symbolizes the general index of $c_{y}$ of the country, $i_{\text {cycoyntry's }} \vee c_{y c o y n t r y}$ is the index of $c_{y}$ of the 
country, and $i_{\text {cyAverage }} \vee c_{y \text { Average }}$ is the global index of $i_{c y}$. Finally, $g_{\text {cyAverage }}$ is the general global index of $c_{y}$, and is obtained as a global constant (Constantinos Challoumis, 2021d).

The proper hypothesis is to establish the connection between the index of global average $c_{y}$, the bank deposits and the GDP per capita, with an econometric approach. Then is confirmed the initial hypothesis that the cycle of money of Greece is above the global average index of the cycle of money. The eq. (4) and (5) mean that an economy close to the value of 0.5 can face immediately an economic crisis. Results close to this value represent an appropriate index of the cycle of money, revealing an adequate economic structure of the society and then the fine distribution of money between the citizens - consumers. Eq. (1) is the term of the cycle of money which used to define the $c_{y c o y n t r y s}$ and $c_{y \text { Average }}$ of eq. (2). The cycle of money to a quantity value is expressed by GDP, basically is an expression of $\frac{\partial(G D P)}{\partial(S+I+X)}$, according to $\frac{d x_{m}}{d m}$ and $-\frac{\partial(G D P)}{\partial\left(S \prime+I^{\prime}+M\right)}$ hinged on $\frac{d x_{m}}{d a}$. Then, $c_{y}=d(G D P)=\frac{\partial(G D P)}{\partial(S+I+X)} d(S+I+X)-\frac{\partial(G D P)}{\partial\left(S^{\prime}+I^{\prime}+M\right)} d\left(S^{\prime}+I^{\prime}+M\right)$, formed on $c_{y}=\frac{d x_{m}}{d m}-\frac{d x_{m}}{d a}$, of eq, (2). Then, $\mathrm{S}$ is the savings, I is the investments and $\mathrm{X}$ is the exports. Then, $\mathrm{S}$, is about the savings which are oriented to banks out of the country's economy, I', is about the investments which oriented to banks out of the country's economy, and $\mathrm{M}$ are the imports. Therefore, the cycle of money expresses the GDP as the following one: $Y=S_{T}+I_{T}+(X-M), \vee Y=\left(S-S^{\prime}\right)+\left(I-I^{\prime}\right)+(X-M) \vee \Upsilon=\Delta S+\Delta I+(X-M)$. According to the theoretical background, for the lost money from the economies, the problem of controlled transactions could be administrated, if an organization could identify the money transitions between the economies, by a comparison of the global economies, by $\Delta \mathrm{S}, \Delta \mathrm{I}$, and $(\mathrm{X}-\mathrm{M})$. Then, $c_{y t o t a l}=\sum_{i=1}^{n} \sum_{t=1}^{m} c_{y i, t}=\sum_{i=1}^{n} \sum_{t=1}^{m}$. But, because data from an organization for these activities don't exist follows the application of the index of the cycle of money. The cycle of money is an expression of the minus between the differential equations of the volume of money that is used in an economy and the volume of money that are lost from the economy. This is the reason why the theory of the cycle of money supports the higher tax of companies that make controlled transactions and the bigger companies because with that way the smaller companies are using an amount of money multiple times. An exemption is for the high technology companies and the factories, where their activities cannot substitute by smaller companies.

The cycle of money expresses the money which is in an economy, and this is reflected in money that has the commercial banks, and extensively the central bank. Therefore, the relation of the country's GDP with the bank deposits allows determining the current amount of money in an economy. In pursuance of prior mathematical background, it is made an econometric analysis of Greece's index of the cycle of money, using Greece's bank deposits per GDP, Greece's GDP per capita, and the global index of the cycle of money. Hence, using eq. (3) - (5), concluded the index of the cycle of money and the general index of the cycle of money, from the country's and global bank deposits, in combination with their GDP's per capita.

\section{Results}

Using the prior methodology extracted the following results. This table has the parameters of bank deposits per GDP, GDPs, and the indexes of the cycle of money. This section reveals the dependence of Greece's index of the cycle of money using the bank deposits of Greece's economy and the GDP per capita of Greece's economy. The bank deposits of the global average case and the global GDP per capita are used for the comparison of Greece's economy, its GDP, and the country's bank deposits.

To the following table is described the variables:

Country's bank deposits per GDP

Country's GDP per capita

Country's index of the cycle of money

Global index of the cycle of money

Country's general index of the cycle of money
Greece's bank deposits per GDP, of Greece for the period of 2012 2017.

Greece's GDP per capita, of Greece for the period of 2012 - 2017.

Greece's indicator of its strength to a crisis, presenting its distribution and reuse of money reflecting its economic structure - expressed as a rate value.

Global indicator of its strength to a crisis, presenting its distribution and reuse of money reflecting its economic structure - expressed as a rate value.

Greece's general indicator of its strength to a crisis, presenting its distribution and reuse of money reflecting its economic structure expressed as a rate value. 
Global general indicator of its strength to a crisis, presenting its Global general index of the cycle of money

distribution and reuse of money reflecting its economic structure -

expressed as a rate value. It' value is estimated to be 0.5 . But, the minimum rate to recover from a crisis is 0.2 .

Proportional conclusions come up and from an econometric point of view, with the dependent variable to be the index of the cycle of money:

Table 1: Greece's OLS regression analysis (Source: author's compilation)

\begin{tabular}{llll}
\hline Variable & Coefficient & std. error & p-value \\
\hline Constant & $-2.32145 \mathrm{e}+06$ & 202146 & $0.0075^{* * *}$ \\
Greece's bank deposits per GDP & 28692.6 & 120.182 & $1.75 \mathrm{e}-05 * * *$ \\
Greece's GDP per capita & 81.7602 & 6.36967 & $0.0060 * * *$ \\
Global index of the cycle of money & -0.0286666 & 0.0222880 & 0.3272 \\
\hline
\end{tabular}

To the prior table, the values with three asterisks are below the 0.01 significant level. The result of the Global average index of the cycle of money has a higher value as it is not directly connected to the country's economy, as there are different estimations for the global case. The Durbin Watson result is 2.263453. The indexes reveal Greece's distribution of money and the form of its economic structure (see Table 2). The first three rows of the table reveal that the p-value is important, therefore the initial hypothesis was rejected and the model is accurate. Pursue to those estimations and the theoretical background is determined the condition of the economic structure of the country and if Greece belongs to the very good economies. Should be mentioned that is used the period of $2012-2017$. It is selected that period as was critical for E.U. as many economic formations happened, especially for countries with high debts; affecting and other economies. According to these results, it's plausible to clarify the condition of the cycle of money in Greece:

Table 2: Greece's index of the cycle of money (Source: Globaleconomy.com and author's compilation)

\begin{tabular}{|c|c|c|c|c|c|c|}
\hline Year & $\begin{array}{l}\text { Bank } \\
\text { Deposits } \\
\text { Global } \\
\text { Average per } \\
\text { GDP }(\%)\end{array}$ & $\begin{array}{l}\text { Bank } \\
\text { Deposits } \\
\text { Greece per } \\
\text { GDP }(\%)\end{array}$ & $\begin{array}{l}\text { Global } \\
\text { GDP per } \\
\text { Capita }(\$)\end{array}$ & $\begin{array}{l}\text { Greece’s } \\
\text { GDP per } \\
\text { Capita }(\$)\end{array}$ & $\begin{array}{l}\text { Index of Global } \\
\text { Average } \mathrm{Cy}(\$)\end{array}$ & $\begin{array}{l}\text { Index of Greece's } \\
\mathrm{Cy}(\$)\end{array}$ \\
\hline 2012 & 52.48 & 88.92 & $16,653.01$ & $28,800.00$ & $873,949.96$ & $2,560,896.00$ \\
\hline 2013 & 53.96 & 91.42 & $17,266.62$ & $28,127.00$ & $931,706.82$ & $2,571,370.34$ \\
\hline 2014 & 55.81 & 93.35 & $17,159.02$ & $28,525.00$ & $957,644.91$ & $2,662,808.75$ \\
\hline 2015 & 59.38 & 82.35 & $15,295.71$ & $28,588.00$ & $908,259.26$ & $2,354,221.80$ \\
\hline 2016 & 60.77 & 71 & $15,330.03$ & $28,652.00$ & $931,605.92$ & 2,034,292.00 \\
\hline 2017 & 60.07 & 70.82 & $15,082.49$ & $29,141.00$ & $906,005.17$ & $2,063,765.62$ \\
\hline RESULTS & & & & & $5,509,172.04$ & $14,247,354.51$ \\
\hline
\end{tabular}

Should be noticed that Bank deposits are used as a percentage of GDP because in that way it is plausible to extract conclusions, about the whole economy per GDP and to make comparisons easier with other countries. Greece's bank deposits: 


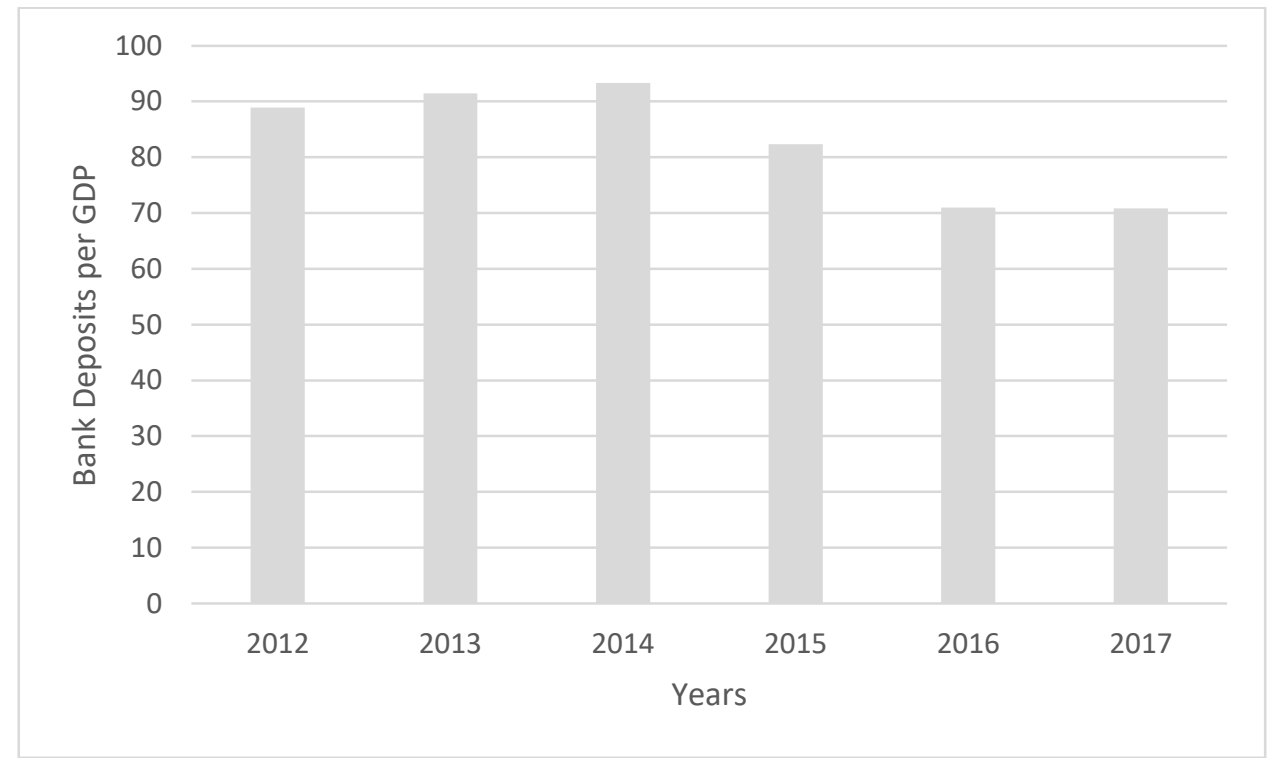

Figure 1. Greece's bank deposits (Source: Globaleconomy.com)

To figure 1 presents the situation of bank deposits of Greece's financial system, as a percent of GDP, for the period from 2012 to 2017. In addition, the next scheme presented the GDPs of Greece:

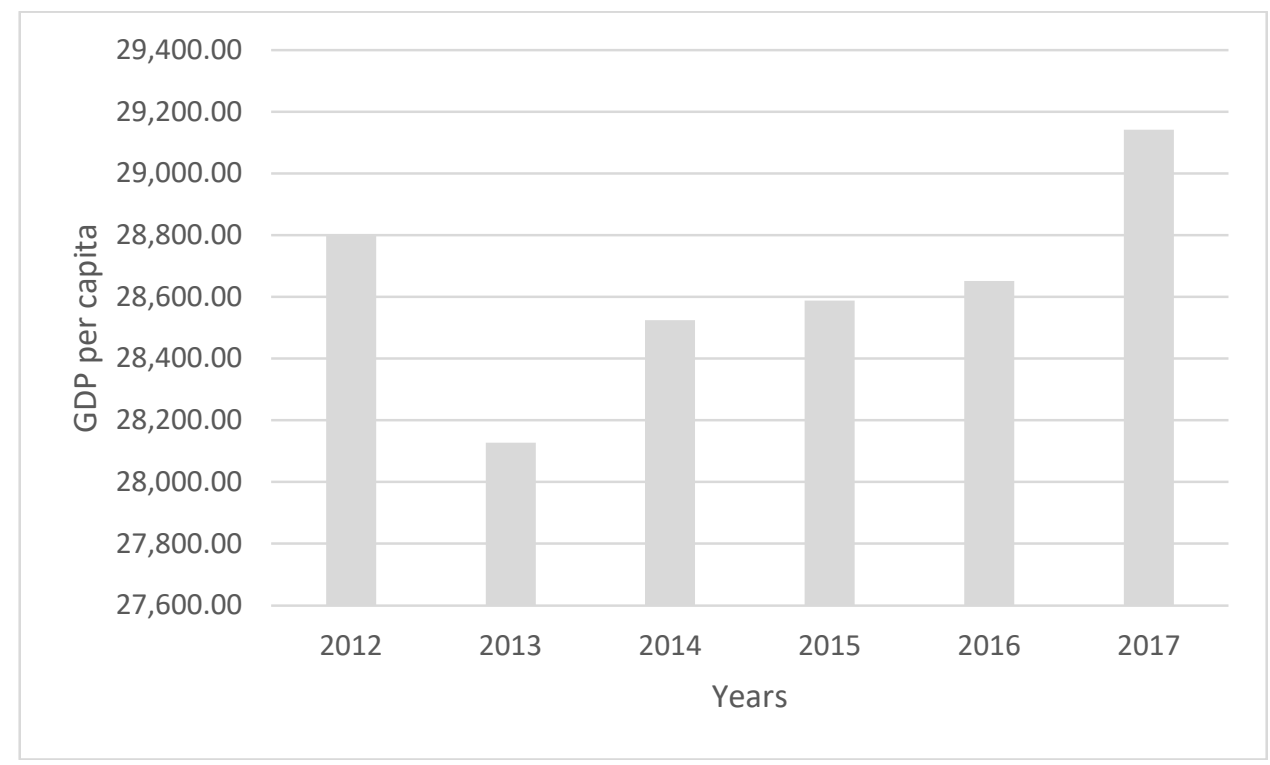

Figure 2. Greece's GDPs per capita (Source: Globaleconomy.com)

Figure 2 presents the condition of the GDPs of Greece's economy for the period from 2012 to 2017. Also, the next scheme presents the GDPs of Greece, for the same period.

According to prior results, the index of Greece's $c_{y}$ is 14,247,354.51 \$

We obtain from the prior results that:

The index of global average $c_{y}$ is $5,509,172.04 \$$

Calculating the general index of the cycle of money for the case of Greece and of global view we have that:

- The general index of $c_{y}$ for Greece is $g_{\text {cyCountry }}=0.72$

- The general index of $c_{y}$ of global view is $g_{\text {cyAverage }}=0.5$

Therefore, it is concluded that Greece's index cycle of money is above the global average cycle of money. Then, the dynamic of Greece's economy complies with the global average and its structure is near to the initial hypothesis. Then we receive the next scheme: 


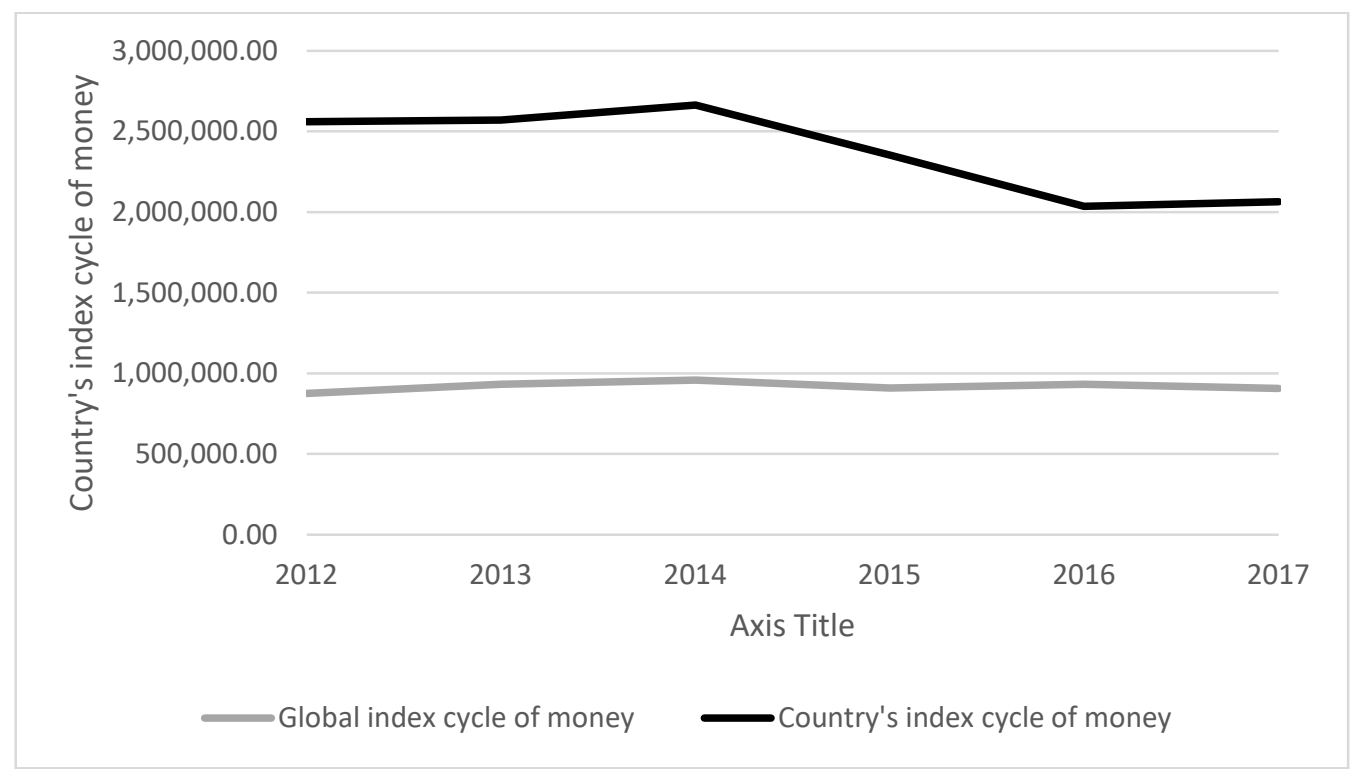

Figure 3. Graph of the index of the cycle of money (Source: author's compilation)

Formed on the prior scheme, it is concluded that the index of the cycle of money of Greece's economy is above the global average of the index of the cycle of money, which is 0.5 (considered as a global constant). Greece's index of the cycle of money is 0.72. Countries over 0.2 can face an economic crisis. As higher is their index, then faster can return to their prior condition. The countries that are near 0.5 have a well-structured economy - standing on eq. (5), according to the theoretical background of the cycle of money. This conclusion means that the economic structure of Greece has an upper distribution of money to its economy. Besides, Greece could proceed to more reforms, as the international and the bigger companies still substitute the local medium and small enterprises. The authorities should apply the fixed-length principle, then higher taxes should be put on the bigger companies. In that way, the distribution of money inside the economy will be increased, and social welfare will be boosted. The government should protect more the small and medium enterprises to avoid losing money from transactions of bigger companies.

The general index of the cycle of money appears to the following figure:

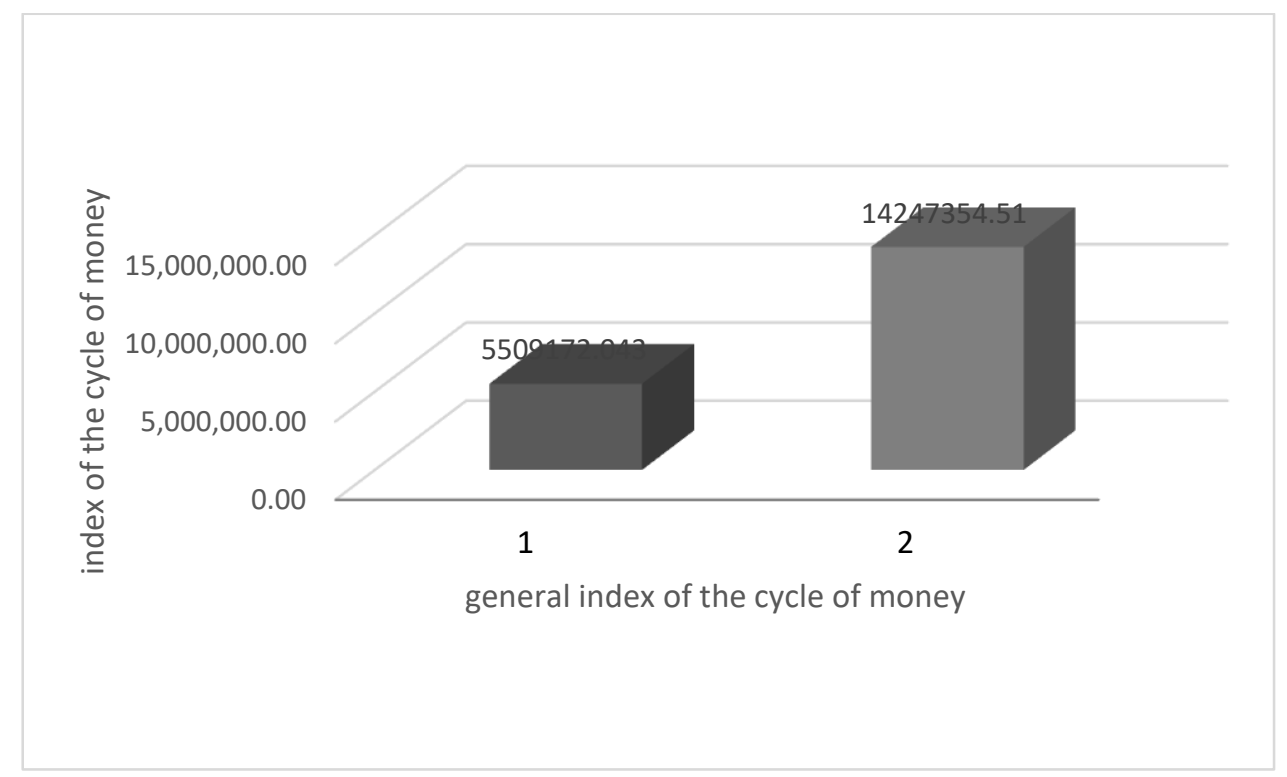

Figure 4. The cycle of money indexes (Source: author's compilation)

The prior scheme has presented the combination of the index of the cycle of money with the case of the general index of the cycle of money. It is represented the affiliation between the global average indexes and Greece's index. Greece is part of the countries which are above the global average index of the cycle of money, both for the simple index and general index.

\section{Discussion}

The current results reveal that Greece's economic system belongs to the upper level of the cycle of money, then there has an upper dynamic. But, Greece's economy could be improved more. The structure of the economy may be improved, with decrease taxes to the small and medium companies, and an increase of taxes to the bigger companies. The bigger 
companies have to provide economic activities that smaller businesses can't support, then the authorities ought to imply low taxes to know-how companies and factories. Consequently, big companies must no longer replace smaller businesses' activities. The investments of a country are boosted by the increase in the distribution of money. A country with a wellbased economic system is a country with a good cycle of money and therefore it can face an economic crisis. Greece's economic system is above the index of common GDP per capita (meaning the value of 0.5 ), from 2012 to 2017 using the index of average GDP per capita. The branches of international banks if are included in the system of the economy are considered as part of this economy, then as international banks are considered the banks which keep the money outside the economic system of each economy (meaning especially banks of tax heavens or international banks which keep money out of the economies as part of black money and huge amounts of money that will not return to the countries' economies). Moreover, if a country has a low rate of bank deposits per GDP, but comply with the theory of the cycle of money, then it is obvious that there is a problem with black money. The black money increases the cycle of money as in some way is reused to the economy but decreases the cycle of money if is deposited outside the economy. So, black money belongs to the grey area, for the economy. But, in any case, the index of the cycle of money reveals if the economy has black money. In addition, the tax policy if it is not able to identify the bigger companies from the smaller companies, means that has a bureaucratic problem, as these identifications should be directly visible for government's data.

The cycle of money supports the free competition and the tax policy of Fixed Length Principle between the economies, and according to them shows the directions that should be followed to the economy is that companies with big capital should be invested in factories and companies of high technological products, not to substitute products and services that can offer smaller companies. Small and medium enterprises are the most accurate and quick way to develop the private sector to a country, making wider the tax bureau minimizing with that way the taxes.

\section{Conclusion}

According to the outcomes of the table, Greece is above the worldwide average index of the cycle of money. From figure 2 and figure 3 the index of the cycle of money is revealed Greece's distribution of money is to the most upper rate. The cycle of money of the country permits a very good distribution of money. The losses of the local banks are to a low degree. But, the country's economy could be better due to the fact an amount of money is excluded from the local financial system by worldwide transactions (see table 2). The current model complies with the initial assumption, showing the distribution of money to Greece's economy. Greece's economic system tends in the last years to have the same reuse of money inside the financial system as in the past, as tends to have the same characteristics as a financial system that complies with the idea of the cycle of money. Greece's financial dynamic is above the worldwide average cycle of money, as the value is 0.72 reveals that Greece's economy tends to have a good distribution of money. Other countries' recent results, as the case of Latvia, Serbia, and Bulgaria, revealed that are close to the global general average index of the cycle of money, meaning that their economic structures and economic functionality are well-based and can face a potential crisis of their economies.

At least, the shadow market is not a problem according to the theory of the cycle of money, as critical is to keep the money to a country's economy and not move them outside it. If money stays in an economy, then it is a matter of time to be taxed or by direct or indirect tax. Then, for this reason, international and big companies should be taxed higher than smaller companies, as they substitute their activities and save their money outside the economy. On the contrary, smaller companies use and reuse their money to the economy and save them to local banks, increasing the cycle of money. The finding of 0.72 is a little bit lower than the 0.79 , which is about the period of $1980-2020$. This means that Greece to the crisis period of $2012-2017$ became a little bit weaker as their rate of the cycle of money declined by 0.07 . The finding of 0.72 indicates that Greece has a very good value of the general index of the cycle of money, meaning that the structure of the economy is very well-based. The distribution and reuse of money permitted it to face its strong economic crisis.

\section{References}

Abdelkafi, I. (2018) 'The Relationship Between Public Debt, Economic Growth, and Monetary Policy: Empirical Evidence from Tunisia', Journal of the Knowledge Economy, 9(4). doi: 10.1007/s13132-016-0404-6.

Acs, Z. et al. (2016) 'Public policy to promote entrepreneurship: a call to arms', Small Business Economics, 47(1). doi: 10.1007/s11187016-9712-2.

Acs, Z. J. and Szerb, L. (2007) 'Entrepreneurship, economic growth and public policy', Small Business Economics, 28(2-3). doi: $10.1007 / \mathrm{s} 11187-006-9012-3$.

AICPA (2017) 'Guiding principles of good tax policy: A framework for evaluating tax proposals', American Institute of Certified Public Accountants, 2017(March 2001).

Arabyan, O. (2016) 'Public infrastructure policies and economic geography', Glasnik Srpskog geografskog drustvaBulletin of the Serbian Geographical Society, 96(1). doi: 10.2298/gsgd1601093a.

Arai, R., Naito, K. and Ono, T. (2018) 'Intergenerational policies, public debt, and economic growth: A politico-economic analysis', Journal of Public Economics, 166. doi: 10.1016/j.jpubeco.2018.08.006.

Bakaki, Z. and Bernauer, T. (2018) 'Do economic conditions affect public support for environmental policy?', Journal of Cleaner Production, 195. doi: 10.1016/j.jclepro.2018.05.162.

Bernasconi, O. and Espinosa-Cristia, J. F. (2020) 'No politics, no society: Questioning the justification of entrepreneurship in chilean public policies', RAE Revista de Administracao de Empresas, 60(2). doi: 10.1590/S0034-759020200206.

Bhuiyan, S. and Farazmand, A. (2020) 'Society and Public Policy in the Middle East and North Africa', International Journal of Public Administration. doi: 10.1080/01900692.2019.1707353. 
Le Bodo, Y. et al. (2019) 'Conditions influencing the adoption of a soda tax for public health: Analysis of the French case (2005-2012)', Food Policy, 88. doi: 10.1016/j.foodpol.2019.101765.

Bowling, S. J., Boyland, L. G. and Kirkeby, K. M. (2019) 'Property Tax Cap Policy in Indiana and Implications for Public School Funding Equity', International Journal of Education Policy and Leadership, 15(9). doi: 10.22230/ijepl.2019v15n9a881.

Cai, Y. (2017) 'Nonlinear Analysis of Economic Growth, Public Debt and Policy Tools', Asian Economic and Financial Review, 7(1). doi: 10.18488/journal.aefr/2017.7.1/102.1.99.108

Campos, J., Braga, V. and Correia, A. (2019) 'Public policies for entrepreneurship and internationalization: Is there a government reputation effect?', Journal of Science and Technology Policy Management, 10(4). doi: 10.1 108/JSTPM-04-2018-0044.

Cascajo, R. et al. (2018) 'Impacts of the economic crisis on household transport expenditure and public transport policy: Evidence from the Spanish case', Transport Policy, 65. doi: 10.1016/j.tranpol.2017.06.001.

Castaño, M. S., Méndez, M. T. and Galindo, M. Á. (2016) 'The effect of public policies on entrepreneurial activity and economic growth', Journal of Business Research, 69(11). doi: 10.1016/j.jbusres.2016.04.125.

Challoumis, C. (2018) 'Methods of Controlled Transactions and the Behavior of Companies According to the Public and Tax Policy', Economics, pp. 33-43. doi: 10.2478/eoik-2018-0003.

Challoumis, C. (2019a) 'The arm's length principle and the fixed length principle economic analysis', World Scientific Neres, 115(2019), pp. 207-217. Available at: http://www.worldscientificnews.com/wp-content/uploads/2018/11/WSN-115-2019-207-2 17.pdf (Accessed: 21 April 2021).

Challoumis, C. (2019b) 'Transfer Pricing Methods for Services and the Policy of Fixed Length Principle', Economics and Business, 33(1), pp. 222-232. doi: https://doi.org/10.2478/eb-2019-0016.

Challoumis, C. (2020) 'Analysis of the Theory of Cycle of Money', Acta Universitatis Bohemiae Meridionalis, 23(2), pp. 13-29. doi: https://doi.org/10.2478/acta-2020-0004.

Challoumis, Constantinos (2020) 'The Impact Factor of Education on the Public Sector - The Case of the U.S.', International Journal of Business and Economic Sciences Applied Research, 13(1), pp. 69-78. doi: 10.25103/ijbesar.131.07.

Constantinos Challoumis (2019) 'Journal Association “SEPIKE” Edition 25, October, 2019', Journal Association SEPIKE, 2019(25), pp. 12-21. Available at: https://5b925ea6-3d4e-40ob-b5f3-

32dc681218ff.filesusr.com/ugd/b199e2_dd29716b8bec48ca8fe7fbcfd47cdd2e.pdf.

Constantinos Challoumis (2021a) 'INDEX OF THE CYCLE OF MONEY - THE CASE OF BULGARIA', Economic Alternatives, 27(2). Available at: https://www.unwe.bg/eajournal/en.

Constantinos Challoumis (2021b) 'Index of the Cycle of Money - The Case of Latvia', Economics and Culture, 17(2), pp. 5-12. doi: $10.2478 /$ jec-2020-0015.

Constantinos Challoumis (2021c) 'Index of the cycle of money - The case of Serbia', OPEN JOURNAL FOR RESEARCH IN ECONOMICS (OJRE), 4(1). Available at: https://centerprode.com/ojre.html.

Constantinos Challoumis (2021d) 'Mathematical background of the theory of cycle of money', SSRN Electronic Journal. Available at: https://papers.ssrn.com/sol3/papers.cfm?abstract_id=3902181.

Cornelsen, L. and Smith, R. D. (2018) 'Viewpoint: Soda taxes - Four questions economists need to address', Food Policy, 74. doi: 10.1016/j.foodpol.2017.12.003.

Erickson, K. (2016) 'Defining the public domain in economic terms - approaches and consequences for policy', Etikk i Praksis. doi: 10.5324/eip.v10i1.1951.

Feinschreiber, R. (2004) Transfer pricing Methods An Application Guide. New Jersey: John Wiley \& Sons.

Forson, J. A. (2020) 'Innovation financing and public policy dilemmas in the Economic Community of West African States (ECOWAS)', African Journal of Science, Technology, Innovation and Development, 12(1). doi: 10.1080/20421338.2019.1599575. GVELESIANI, R. (2019) 'COMPATIBILITY PROBLEM OF BASIC PUBLIC VALUES WITH ECONOMIC POLICY GOALS AND DECISIONS FOR THEIR IMPLEMENTATION', Globalization and Business, 4(7). doi: 10.35945/gb.2019.07.004. Haskel, J. and Westlake, S. (2021) 'Capitalism without capital: The rise of the intangible economy (an excerpt)', Ekonomicheskaya Sotsiologiya, 22(1). doi: 10.17323/1726-3247-202 1-1-61-70.

'Income taxes, public fiscal policy and economic growth' (2014) E-Finanse, 10(3). doi: 10.14636/1734-039X_10_3_001.

Jeon, J., Kim, S. and Kwon, S. M. (2020) 'The effects of urban containment policies on public health', International Journal of Environmental Research and Public Health, 17(9). doi: 10.3390/ijerph 17093275.

Jia, M. et al. (2020) 'Public policy change and its impact on urban expansion: An evaluation of 265 cities in China', Land Use Policy, 97. doi: 10.1016/j.landusepol.2020.104754.

Jomo, K. S. and Wee, C. H. (2003) 'The political economy of Malaysian federalism: Economic development, public policy and conflict containment', Journal of International Development, 15(4). doi: 10.1002/jid.995.

Kalambokidis, L. (2014) 'Creating public value with tax and spending policies: The view from public economics', Public Administration Review, 74(4). doi: 10.1111/puar.12162.

Korenik, D. and Wegrzyn, M. (2020) 'Public policy timing in a sustainable approach to shaping public policy', Sustainability (Switzerland), 12(7). doi: 10.3390/su12072677.

Kroth, D. C., Geremia, D. S. and Mussio, B. R. (2020) 'National school feeding program: A healthy public policy', Ciencia e Saude Coletiva, 25(10). doi: 10.1590/1413-812320202510.31762018.

Ladvocat, M. and Lucas, V. (2019) 'REGIONAL DISPARITIES, PUBLIC POLICIES AND ECONOMIC GROWTH IN BRAZIL',

Revista Baru - Revista Brasileira de Assuntos Regionais e Urbanos, 5(2). doi: 10.18224/baru.v5i2.7687.

Lajas, R. and Macário, R. (2020) 'Public policy framework supporting “mobility-as-a-service” implementation', Research in Transportation Economics, 83. doi: 10.1016/j.retrec.2020.100905.

Marume, S. B. M. (2016) 'Public Policy and Factors Influencing Public Policy', International Journal of Engineering Science Invention, $5(6)$.

Maxwell, J. A. (2020) 'The Value of Qualitative Inquiry for Public Policy’, Qualitative Inquiry, 26(2). doi: 10.1177/1077800419857093. Miailhe, N. (2017) 'Economic, Social and Public Policy Opportunities enabled by Automation', Field Actions Science Reports. The journal offield actions, (Special Issue 17).

Montmarquette, C. (2020) 'From economic analysis to public policies in the economics of education', Revue Economique. doi:

$10.3917 /$ reco.716.0943.

Mueller, B. (2020) 'Why public policies fail: Policymaking under complexity', EconomiA, 21(2). doi: 10.1016/j.econ.2019.1 1.002. 
Oueslati, W. (2015) 'Growth and welfare effects of environmental tax reform and public spending policy', Economic Modelling, 45. doi: 10.1016/j.econmod.2014.10.040.

Pircher, B. (2020) 'EU public procurement policy: the economic crisis as trigger for enhanced harmonisation', Journal of European Integration, 42(4). doi: 10.1080/07036337.2019.1666114.

Porter, M. E. (2007) 'Clusters and Economic Policy: Aligning Public Policy with the New Economics of Competition', Business, (November).

Rashid, H., Warsame, H. and Khan, S. (2020) 'The Differential Impact of Democracy on Tax Revenues in Developing and Developed Countries', International Journal of Public Administration. doi: 10.1080/01900692.2020.1741616.

Rumayya et al. (2020) 'The local economy and Re-election of incumbent district leaders in Indonesia', Heliyon, 6(5). doi:

$10.1016 /$ j.heliyon.2020.e04098.

Stern, N. (2015) 'Economic development, climate and values: Making policy', Proceedings of the Royal Society B: Biological Sciences, 282(1812). doi: 10.1098/rspb.2015.0820.

'The East Asian miracle: economic growth and public policy' (1994) Choice Reviews Online, 32(02). doi: 10.5860/choice.32-1052

Tvaronavičienè, M., Tarkhanova, E. and Durglishvili, N. (2018) 'Sustainable economic growth and innovative development of educational systems', Journal of International Studies, 1 1(1). doi: 10.14254/2071-8330.2018/11-1/19.

Ud Din, M., Mangla, I. U. and Jamil, M. (2016) 'Public Policy, Innovation and Economic Growth: An Economic and Technological Perspective on Pakistan's Telecom Industry', THE LAHORE JOURNAL OF ECONOMICS, 2 (Special Edition). doi: 10.35536/lje.2016.v21.isp.a16.

Wu, J. et al. (2019) 'Changing distribution of migrant population and its influencing factors in urban China: Economic transition, public policy, and amenities', Habitat International, 94. doi: 10.1016/j.habitatint.2019.102063.

This is an Open Access article distributed under the terms of the Creative Commons Attribution Licence

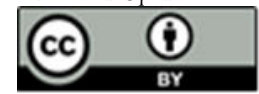

